\title{
Photobacterium kishitanii sp. nov., a luminous marine bacterium symbiotic with deep-sea fishes
}

Correspondence Jennifer C. Ast jca@umich.edu

\author{
Jennifer C. Ast, ${ }^{1}$ Ilse Cleenwerck, ${ }^{2}$ Katrien Engelbeen, ${ }^{2}$ \\ Henryk Urbanczyk, ${ }^{1}$ Fabiano L. Thompson, ${ }^{3}$ Paul De Vos ${ }^{2}$ \\ and Paul V. Dunlap ${ }^{1}$
${ }^{1}$ Department of Ecology and Evolutionary Biology, University of Michigan, Ann Arbor, MI, USA
${ }^{2}$ Laboratory of Microbiology and BCCM/LMG Bacteria Collection, Ghent University, K. L. Ledeganckstraat 35, Ghent 9000, Belgium
${ }^{3}$ Department of Genetics, Federal University of Rio de Janeiro, Ilha do Fundão, CEP 21944-970, Rio de Janeiro, Brazil

\begin{abstract}
Six representatives of a luminous bacterium commonly found in association with deep, colddwelling marine fishes were isolated from the light organs and skin of different fish species. These bacteria were Gram-negative, catalase-positive, and weakly oxidase-positive or oxidase-negative. Morphologically, cells of these strains were coccoid or coccoid-rods, occurring singly or in pairs, and motile by means of polar flagellation. After growth on seawater-based agar medium at $22{ }^{\circ} \mathrm{C}$ for $18 \mathrm{~h}$, colonies were small, round and white, with an intense cerulean blue luminescence. Analysis of $16 \mathrm{~S}$ rRNA gene sequence similarity placed these bacteria in the genus Photobacterium. Phylogenetic analysis based on seven housekeeping gene sequences (16S rRNA gene, gapA, gyrB, pyrH, recA, rpoA and rpoD), seven gene sequences of the lux operon ( $\operatorname{ux} C, \operatorname{lu} x D, \operatorname{lu} x A$, IuxB, IuxF, luxE and IuxG) and four gene sequences of the rib operon (ribE, $\mathrm{ribB}, \mathrm{ribH}$ and $\mathrm{ribA}$ ), resolved the six strains as members of the genus Photobacterium and as a clade distinct from other species of Photobacterium. These strains were most closely related to Photobacterium phosphoreum and Photobacterium iliopiscarium. DNA-DNA hybridization values between the designated type strain, Photobacterium kishitanii pjapo.1.1 ${ }^{\top}$, and $P$. phosphoreum LMG $4233^{\top}$, P. iliopiscarium LMG $19543^{\top}$ and Photobacterium indicum LMG $22857^{\top}$ were 51 , 43 and $19 \%$, respectively. In AFLP analysis, the six strains clustered together, forming a group distinct from other analysed species. The fatty acid $\mathrm{C}_{17: 0}$ cyclo was present in these bacteria, but not in $P$. phosphoreum, $P$. iliopiscarium or $P$. indicum. A combination of biochemical tests (arginine dihydrolase and lysine decarboxylase) differentiates these strains from $P$. phosphoreum and $P$. indicum. The DNA G $+C$ content of $P$. kishitanii pjapo. $1.1^{\top}$ is $40.2 \%$, and the genome size is approximately $4.2 \mathrm{Mbp}$, in the form of two circular chromosomes. These strains represent a novel species, for which the name Photobacterium kishitanii sp. nov. is proposed. The type strain, pjapo. $1.1^{\top}$ (=ATCC BAA-1194 ${ }^{\top}=$ LMG $23890^{\top}$ ), is a luminous symbiont isolated from the light organ of the deep-water fish Physiculus japonicus.
\end{abstract}

Photobacterium (Gammaproteobacteria: Vibrionaceae) comprises at present 14 species with validly published names, many members of which are luminous and some of which enter into bioluminescent symbioses with marine animals (Dunlap \& Kita-Tsukamoto, 2006; Dunlap et al.,

Abbreviations: AFLP, amplified length polymorphisms; Mbp, mega base pairs.

The GenBank/EMBL/DDBJ accession number for gene sequences reported in this paper are EF415487-EF415631 and EF441349.

Supplementary material is available with the online version of this paper.
2007). Photobacterium phosphoreum (Beijerinck, 1889), the type species of the genus Photobacterium, was thought to be the light-organ symbiont of deep-water fishes (Hastings \& Nealson, 1981), although the type strain of this species was isolated from the surface of a non-luminous fish (Ast \& Dunlap, 2005). Recent analyses showed that P. phosphoreum was not recovered from light organ symbiosis; instead, the light-organ symbionts of deep-sea fishes formed a clade distinct from $P$. phosphoreum, designated previously as Photobacterium kishitanii (Dunlap \& Ast, 2005; Dunlap et al., 2007). P. kishitanii is closely related to $P$. phosphoreum and Photobacterium iliopiscarium, although 
based on phylogenetic analysis, the latter two species are more closely related to each other than either is to $P$. kishitanii (Ast \& Dunlap, 2005). Here, we present comprehensive phylogenetic, genomic and phenotypic evidence that strains of $P$. kishitanii represent a novel species, within the genus Photobacterium, for which the name Photobacterium kishitanii sp. nov. is proposed. The type strain is pjapo.1.1 ${ }^{\mathrm{T}} \quad\left(=\mathrm{ATCC}\right.$ BAA- $1194^{\mathrm{T}}=\mathrm{LMG}$ $23890^{\mathrm{T}}$ ).

Six strains representing $P$. kishitanii sp. nov. were examined here (Table 1), three isolated from fish light-organs (Ast \& Dunlap, 2005; Dunlap \& Ast, 2005; Haygood et al., 1992) and three from enrichments of fish skin (Ast \& Dunlap, 2005; Hendrie et al., 1970; Georgala, 1958; Reichelt \& Baumann, 1973). To obtain DNA sequences for phylogenetic analysis, genomic DNA was purified using a DNA extraction kit (Qiagen) following the manufacturer's protocol for Gram-negative bacteria. Seven housekeeping genes (16S rRNA, gapA, gyrB, pyrH, recA, rpoA and rpoD) were amplified from the six strains and from eleven representative strains of the genus Photobacterium. In addition, the genes of two contiguous operons, the lux operon $(\operatorname{lu} x C, \operatorname{lu} x D, \operatorname{lu} x A, \operatorname{lu} x B, \operatorname{lu} x F, \operatorname{lu} x E$ and $\operatorname{lu} x G$, the products of which are responsible for the luminescent phenotype) and the rib operon ( $r i b E, r i b B, r i b H$ and $r i b A$, the products of which are involved in riboflavin synthesis) were amplified from luminous strains, for a total of more than $17 \mathrm{kbp}$ of sequence. See Supplementary Tables S1-S4 for PCR amplification profiles and primer sequences (available in IJSEM Online). Amplified products were purified by using a PCR clean-up kit (Millipore) and directly sequenced by using the University of Michigan Sequencing Core. Sequences for housekeeping, lux and rib genes were obtained for two strains of Vibrio fischeri to serve as outgroups. GenBank accession numbers for all DNA sequences, including those obtained previously, are listed in Supplementary Table S5.

To test the evolutionary relationships of these six strains to other species of the genus Photobacterium, phylogenetic analysis was performed on the concatenated dataset with the program PAUP* (Swofford, 2002) using the 18 genes listed above (see Supplementary Material for details of phylogenetic analysis). Support values were calculated using 5000 jackknife resampling replicates. The resulting most parsimonious phylogenetic hypothesis clearly demonstrates that the novel strains identified as $P$. kishitanii represent a lineage separate from other species of Photobacterium (Fig. 1), with robust resampling support. Within the genus Photobacterium, the representatives of $P$. kishitanii form a clade with the species $P$. phosphoreum and P. iliopiscarium.

To test further the hypothesis that $P$. kishitanii is a separate species, several additional analyses were performed. For per cent identities among $16 \mathrm{~S}$ rRNA gene sequences, sequences were aligned using direct optimization analysis (Wheeler, 1996; Wheeler et al., 2006), as implemented by the program POY (Wheeler et al., 2003). Direct optimization iteratively evaluates alignment in the context of phylogeny; it therefore produces a rigorously tested alignment, unlike single-pass multiple sequence alignment algorithms used by other alignment programs. Details of the POY analysis can be found in Supplementary Material. Identities of $P$. kishitanii pjapo.1.1 $1^{\mathrm{T}}$ to other species were $97.7 \%$ to $P$. indicum LMG $22857^{\mathrm{T}}, 99.6 \%$ to $P$. iliopiscarium LMG $19543^{\mathrm{T}}$ and $99.7 \%$ to $P$. phosphoreum LMG $4233^{\mathrm{T}}$. These values are within the range of per cent identities between other recognized species of Photobacterium; for example, the identity between $P$. indicum LMG $22857^{\mathrm{T}}$ and $P$. phosphoreum LMG $4233^{\mathrm{T}}$ is $97.9 \%$.

To characterize genomic features that distinguish the strains of $P$. kishitanii from other species of Photobacterium, we performed two tests of genomic similarity, DNA-DNA hybridization and amplified length fragment polymorphism (AFLP) analysis. For DNA-DNA hybridization, high molecular mass DNA was prepared by the method of Wilson (1987) with minor modifications (Cleenwerck et al., 2002). DNA quality and quantity were determined by measuring absorptions at 260, 280 and $234 \mathrm{~nm}$. Only high quality DNA with $A_{260} / A_{280}$ and $A_{234} /$ $A_{260}$ ratios of $1.8-2.0$ and $0.40-0.60$ was used. Hybridizations were performed using a modification (Goris et al., 1998; Cleenwerck et al., 2002) of the microplate method described by Ezaki et al. (1989) with a hybridization temperature of $37{ }^{\circ} \mathrm{C}$. Reported values are

Table 1. Source of the novel strains investigated in this study

LO, Light organ; skin, enrichment from fish skin.

\begin{tabular}{|lll|}
\hline \multicolumn{1}{|c|}{ Strain } & \multicolumn{1}{c|}{ Previous designation; origin } & \multicolumn{1}{c|}{ Reference } \\
\hline LMG 23890 & ATCC BAA-1194 ${ }^{\mathrm{T}}$, pjapo.1.1 ${ }^{\mathrm{T}}$; LO, Physiculus japonicus, Japan, 1982 & Dunlap \& Ast (2005), Ast \& Dunlap (2005) \\
LMG 23891 & ckamo.1.1; LO, Caelorinchus kamoharai, Japan, 2004 & Ast \& Dunlap (2005) \\
LMG 23892 & Og61; LO, Opisthoproctis grimaldii, Cape Verde, 1990 & Haygood et al. (1992) \\
LMG 23893 & B-421; skin, Trachurops crumenophthalmus, Hawaii, 1973 & Reichelt \& Baumann (1973) \\
LMG 23894 & FS-8.1; skin, 'bluenosed grouper', Florida, 2003 & Ast \& Dunlap (2005) \\
LMG 23895 & NCIMB 844; skin, Merluccius capensis, South Africa, 1958 & Georgala (1958); D. L. Georgala, personal com- \\
& & munication \\
\hline
\end{tabular}




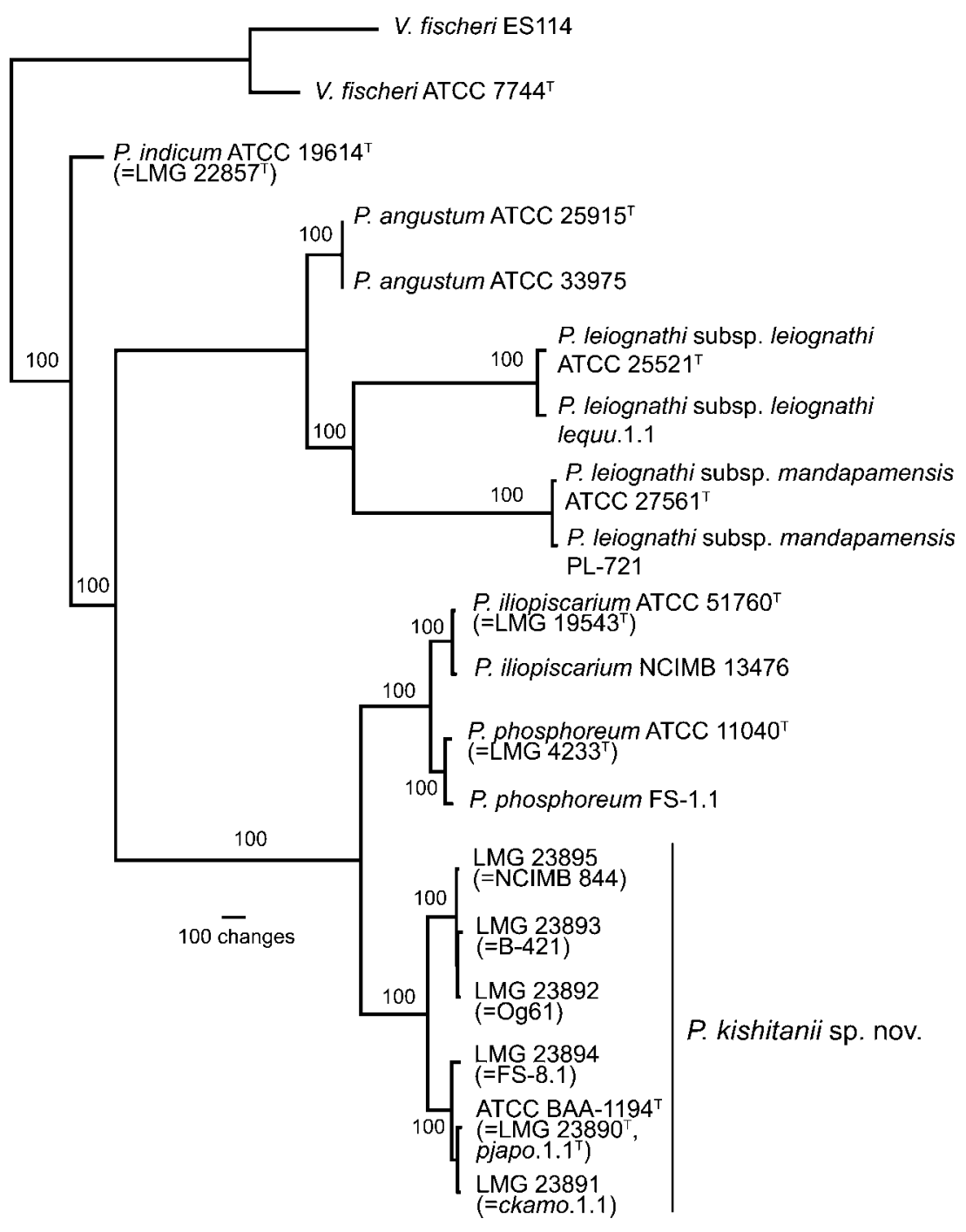

Fig. 1. Phylogenetic tree of Photobacterium including the six strains of $P$. kishitanii sp. nov. Parsimony analysis of the concatenated dataset comprising seven housekeeping gene sequences (16S rRNA, gap $A$, gyr $B$, pyrH, $\operatorname{rec} A, r p o A$ and $r p o D$ ), seven gene sequences of the lux operon ( $\operatorname{lux} C, \operatorname{lu} x D, \operatorname{lu} x A, \operatorname{lu} x B, \operatorname{lu} x F$, luxE and I $u x G$ ) and four gene sequences of the rib operon ( $r i b E, r i b B, r i b H$ and ribA) resulted in the single most parsimonious hypothesis shown here (5018 informative characters, tree length $=8540$, ensemble consistency index $=$ 0.808 , ensemble retention index $=0.877$ ). Inferred gaps were treated as informative data, and for taxa lacking lux and rib genes or operons, the missing genes were treated as missing data. Numbers at nodes are jackknife support values based on 5000 resampling replicates. the mean of a minimum of four hybridizations. The values for hybridization between strain P. kishitanii pjapo. $1.1^{\mathrm{T}}$ and other species of Photobacterium were $51 \%$ to P. phosphoreum LMG $4233^{\mathrm{T}}, 43 \%$ to $P$. iliopiscarium LMG $19543^{\mathrm{T}}$ and $19 \%$ to $P$. indicum LMG $22857^{\mathrm{T}}$. These values, which are below the current level that delimits separate species, demonstrates that strains of $P$. kishitanii are distinct from other species of Photobacterium.

For AFLP analysis, DNA was prepared as above, and template preparation, PCR reactions and PAGE were performed as described by Thompson et al. (2001). Electrophoretic patterns were tracked and normalized using the GENESCAN 3.1 software (Applera). Normalized tables of peaks, containing fragments of 50-539 bp were transferred to the BioNumerics 4.5 software (Applied Maths) for numerical analysis. Patterns were clustered using the Dice coefficient and the UPGMA algorithm. A band position tolerance value of $0.3 \%$ was allowed to compensate for misalignment of similarly sized bands due to technical imperfections. The profiles were compared with the profiles of other species of Vibrionaceae using the database at the BCCM/LMG Bacteria Collection. The dendrogram of the AFLP profiles demonstrates that the strains of $P$. kishitanii cluster together and are clearly distinct from other analysed species of Photobacterium and Vibrio (Fig. 2).

For determination of whole-cell fatty acid content of strains of $P$. kishitanii compared with strains of $P$. phosphoreum, $P$. iliopiscarium and $P$. indicum, cells were grown for $24 \mathrm{~h}$ at $20{ }^{\circ} \mathrm{C}$ on plates of M12 (Marine agar; Difco) medium. Harvesting of cells conformed to the recommendations of the manufacturer of the MIDI identification system (Microbial Identification System) for $P$. indicum LMG $22857^{\mathrm{T}}$. In the case of the strains of P. kishitanii, cells of all strains were harvested from two plates, and for $P$. phosphoreum LMG $4233^{\mathrm{T}}$ and $P$. iliopiscarium LMG $19543^{\mathrm{T}}$, the complete growth on one plate was used to acquire a sufficient concentration of fatty acids for the analysis. Extraction and analysis were performed according the manufacturer's instructions. The 




Fig. 2. Dendrogram of AFLP patterns of novel strains of $P$. kishitanii compared with other species of Photobacterium and Vibrio. The six strains of $P$. kishitanii (numbers 10-15) are in bold. Numbers represent the following strains: 1 , Photobacterium damselae subsp. damselae LMG $7892^{\top} ; 2$, V. fischeri LMG $4414^{\top} ; 3$, Vibrio harveyi LMG $4044^{\top} ; 4$, P. iliopiscarium LMG $19543^{\top} ; 5$, Photobacterium angustum LMG 8455'; ${ }^{\top}$, Photobacterium leiognathi LMG 4228 ${ }^{\top} ; 7$, P. phosphoreum LMG $4233^{\top}$; 8, Photobacterium profundum LMG $19446^{\top}$; 9 , Photobacterium rosenbergii LMG $22223^{\top} ; 10$, P. kishitanii sp. nov. Og61 (=LMG 23892); 11, P. kishitanii sp. nov. B-421 (=LMG 23893); 12, P. kishitanii sp. nov. NCIMB 844 (=LMG 23895); 13, P. kishitanii sp. nov. ckamo.1.1 (=LMG 23891); 14, P. kishitanii sp. nov. FS-8.1 (=LMG 23894); 15, P. kishitanii sp. nov. pjapo.1.1 ${ }^{\top}$ (=LMG $\left.23890^{\top}\right) ; 16$, P. lipolyticum LMG $23071^{\top}$.

overall profiles of the four tested species are similar (Supplementary Table S6), but strains of P. kishitanii differ by the presence of the fatty acid $\mathrm{C}_{17: 0}$ cyclo, which is not present in strains of $P$. phosphoreum, $P$. iliopiscarium or $P$. indicum.

Phenotypic characterizations, e.g. cell morphology, response to Gram staining, motility, oxidase and catalase tests were performed using standard methods. Additional biochemical tests were performed using API 20E and API 20NE tests (bioMérieux). Cells for inoculation of the strips were grown for $24 \mathrm{~h}$ at $20{ }^{\circ} \mathrm{C}$ on M12 medium and results were visually interpreted according to the manufacturer's instructions. On the basis of the arginine dihydrolase test, novel strains of $P$. kishitanii can be differentiated from strains of $P$. phosphoreum, and the lysine decarboxylase test differentiates novel strains of $P$. kishitanii from strains of $P$. phosphoreum and $P$. indicum. However, no single biochemical trait or combination of traits distinguishes strains of $P$. kishitanii from strains of P. iliopiscarium. Complete phenotype data may be found in Supplementary Table S7.

To characterize further P. kishitanii pjapo.1.1 ${ }^{\mathrm{T}}$, DNA base composition was determined by HPLC according to the method of Mesbah et al. (1989). Non-methylated phage $\lambda$ was used as a reference. The DNA G+C content of $P$. kishitanii pjapo.1.1 $1^{\mathrm{T}}$ is $40.2 \mathrm{~mol} \%$, which is consistent with other species of Photobacterium (Baumann \& Baumann, 1984).

To estimate genome size and chromosome composition, genomic DNA inserts were prepared according to Lucangeli et al. (2000) with modifications. DNA fragments of undigested inserts and inserts digested with NotI or
I-CeuI enzyme (New England Biolabs) were separated by PFGE using standard conditions (see Supplementary Material). Based on the electrophoretic banding patterns, the P. kishitanii pjapo.1.1 $1^{\mathrm{T}}$ genome is approximately 4.2 Mbp, configured in two circular chromosomes of sizes about 2.8 and 1.4 Mbp (Fig. 3). Strains B-421, ckamo.1.1, FS-8.1 and NCIMB 844 have genome sizes ranging from 4.0 to $4.7 \mathrm{Mbp}$ (data not shown). Similar analyses of the genomes of 27 additional strains of $P$. kishitanii (data not shown) revealed that genomes can range in size from 3.9 to $4.9 \mathrm{Mbp}$ with an average of $4.2 \mathrm{Mbp}$; all analysed strains were found to have two circular chromosomes, as in other species of Vibrionaceae (Okada et al., 2005). The I-CeuI enzyme digestion resulted in eight fragments, suggesting that P. kishitanii pjapo.1.1 $1^{\mathrm{T}}$ has at least eight $r r n$ loci $(I-$ $\mathrm{CeuI}$ cuts most bacterial genomes only within $r r n$ loci), a result consistent with the high rrn copy number in other species of Vibrionaceae (Klappenbach et al., 2001).

Culture collections currently hold many bacterial strains identified as $P$. phosphoreum. To test if any of these strains are in fact of $P$. kishitanii, we analysed them phylogenetically by using gene sequences of $\operatorname{gyr} B, \operatorname{rec} A$ and $\operatorname{lux} A$. Gene sequences were aligned by inferred amino acid sequence and analysed with a heuristic parsimony search using the program TNT (Goloboff et al., 2005; analysis details can be found in Supplementary Material). These results indicate that the following strains should be reclassified as $P$. kishitanii sp. nov.: ATCC 35080, ATCC 35081, ATCC 35082, NCIMB 61, NCIMB 62, NCIMB 64, NCIMB 65, NCIMB 66, NCIMB 68, NCIMB 69, NCIMB 70, NCIMB 71, NCIMB 844, NCIMB 1276, NCIMB 1277, NCIMB 12838 and NCIMB 12839. The following strains were 


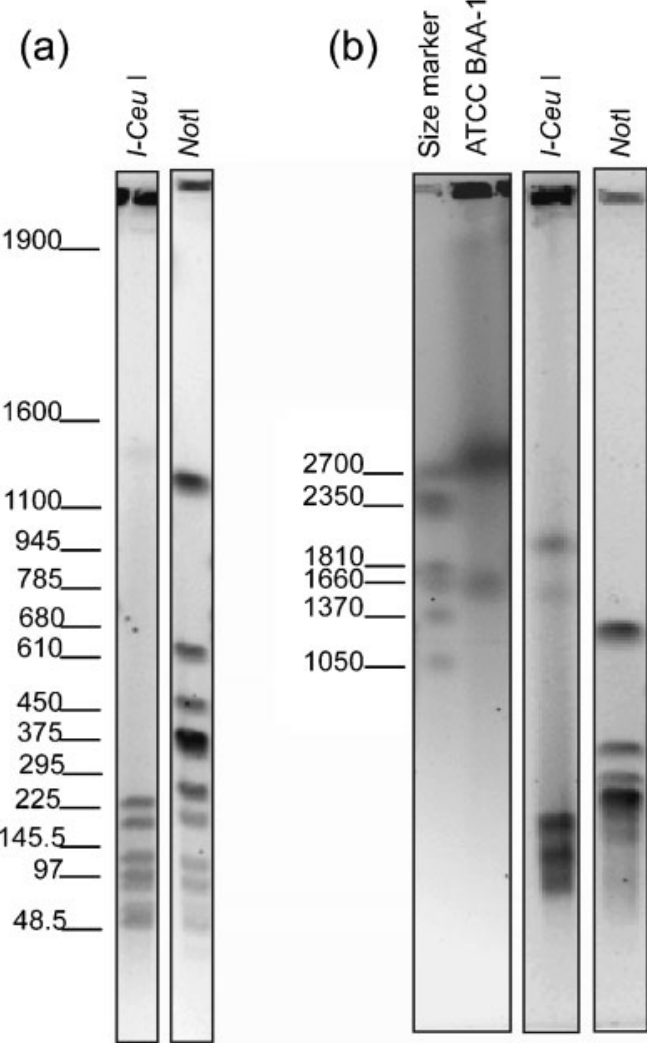

Fig. 3. PFGE of $P$. kishitanii pjapo. $1.1^{\top}$ genomic DNA. Sizes in kb are shown on the left of each picture. (a) Resolution of mid-sized, restriction enzyme digested genomic DNA. (b) Resolution of undigested genomic DNA and large-size, restriction enzyme digested fragments.

confirmed as belonging to $P$. phosphoreum: NCIMB 7, NCIMB 188, NCIMB 193, NCIMB 395, NCIMB 1275 and NCIMB 1279. In previous work (Ast \& Dunlap, 2005), three other strains from NCIMB identified as belonging to the species $P$. phosphoreum were resolved as belonging to the species $P$. iliopiscarium (NCIMB 13476, NCIMB 14378 and NCIMB 13481). A phylogenetic tree showing the results from the analysis including all NCIMB and ATCC strains mentioned above is available as Supplementary Fig. S1. All of these strains that originated from fish lightorgans are P. kishitanii sp. nov., and to date, no strain identified by these criteria as $P$. phosphoreum has been isolated from the light organ of a fish or a squid (Ast \& Dunlap, 2005; Dunlap \& Ast, 2005; Dunlap et al., 2007; this study). Therefore, in contrast to P. kishitanii sp. nov., which can be isolated from light organs of several deep, cold-dwelling fishes, strains of $P$. phosphoreum apparently do not occur as a bioluminescent symbiont of marine animals.

On the basis of these phylogenetic, genomic and taxonomic analyses, strains identified as P. kishitanii clearly represent a separate species of Photobacterium, for which the name Photobacterium kishitanii sp. nov. is proposed.

\section{Description of Photobacterium kishitanii sp. nov.}

Photobacterium kishitanii (ki.shi.tan'i.i. N.L. gen. n. kishitanii of Kishitani, to honour the deceased Japanese scientist Teijiro Kishitani, who first isolated luminous bacteria from the light organ of Physiculus japonicus). The following description is based on analyses of six strains (Table 1).

Cells are Gram-negative, coccoid or coccoid-rods, motile, occurring singly or in pairs, $0.9 \mu \mathrm{m}$ in width by $1.2-3.0 \mu \mathrm{m}$ in length. After $18 \mathrm{~h}$, colonies grown on LSW-70 at $22{ }^{\circ} \mathrm{C}$ are small, round, white and strongly luminous. Catalasepositive. Oxidase-negative or weakly positive. Genome size of the type strain is approximately $4.2 \mathrm{Mbp}$ (ranging within the six strains from 4.0 to $4.7 \mathrm{Mbp}$ ), consisting of two circular chromosomes. Cells produce the fatty acid $\mathrm{C}_{17: 0}$ cyclo. Light-organ symbiont of many fishes, may also be found on the surfaces of fishes and in seawater. The DNA G + C content of the type strain is $40.2 \mathrm{~mol} \%$.

The type strain, pjapo. $1.1^{\mathrm{T}}$ (=ATCC BAA- $1194^{\mathrm{T}}=\mathrm{LMG}$ $23890^{\mathrm{T}}$ ), was isolated in 1982 from the light organ of the deep-sea fish Physiculus japonicus.

\section{Acknowledgements}

We thank Marjan De Wachter for performing the AFLP analyses, Margo Haygood for the gift of strain Og61 and Doug Georgala for information regarding the ecological origin of NCIMB 844. DNA sequencing was carried out by the staff of the University of Michigan Sequencing Core. This work was supported by grant DEB 0413441 from the National Science Foundation. F. L. T. acknowledges a young researcher grant FAPESP no. 04/00814-09. The BCCM/LMG Bacteria Collection is supported by the Federal Public Planning Service Science Policy, Belgium.

\section{References}

Ast, J. C. \& Dunlap, P. V. (2005). Phylogenetic resolution and habitat specificity of members of the Photobacterium phosphoreum species group. Environ Microbiol 7, 1641-1654.

Baumann, P. \& Baumann, L. (1984). Section 5, Family II, Genus II. Photobacterium Beijerinck 1889. In Bergey's Manual of Systematic Bacteriology, vol. 1, pp. 539-545. Edited by N. R. Krieg. Baltimore, MD: Williams \& Wilkins.

Beijerinck, M. W. (1889). Photobacterium luminosum, a luminous bacterium from the North Sea (Le Photobacterium luminosum, Bactérie lumineuse de la Mer du Nord). Translated from Archives Néederlandaises des Sciences Exactes et Naturelles, 23, 401-427 (M. A. Gradstein \& C. D. Lichtfield, transl.) In Marine Microbiology, pp. 16-25. Edited by C. D. Lichtfield. Stroudsberg, PA: Dowden, Hutchinson \& Ross.

Cleenwerck, I., Vandemeulebroecke, K., Janssens, D. \& Swings, J. (2002). Re-examination of the genus Acetobacter, with descriptions of Acetobacter cerevisiae sp. nov. and Acetobacter malorum sp. nov. Int $J$ Syst Evol Microbiol 52, 1551-1588.

Dunlap, P. V. \& Ast, J. C. (2005). Genomic and phylogenetic characterization of luminous bacteria symbiotic with the deep-sea 
fish Chlorophthalmus albatrossis (Aulopiformes: Chlorophthalmidae). Appl Environ Microbiol 71, 930-939.

Dunlap, P. V. \& Kita-Tsukamoto, K. (2006). Luminous bacteria. In The Prokaryotes: a Handbook on the Biology of Bacteria, 3rd edn, vol. 3, pp. 863-892. Edited by M. Dworkin, S. Falkow, E. Rosenberg, K.-H. Schleifer \& E. Stackebrandt. New York: Springer.

Dunlap, P. V., Ast, J. C., Kimura, S., Fukui, A., Yoshino, T. \& Endo, H. (2007). Phylogenetic analysis of host-symbiont specificity and codivergence in bioluminescent symbiosis. Cladistics (in press).

Ezaki, T., Hashimoto, Y. \& Yabuuchi, E. (1989). Fluorometric deoxyribonucleic acid-deoxyribonucleic acid hybridization in microdilution wells as an alternative to membrane filter hybridization in which radioisotopes are used to determine genetic relatedness among bacterial strains. Int J Syst Bacteriol 39, 224-229.

Georgala, D. L. (1958). The bacterial flora of the skin of North Sea cod. J Gen Microbiol 18, 84-91.

Goloboff, P. A., Farris, J. S. \& Nixon, K. C. (2005). TNT - Tree Analysis Using New Technology, version 1.0 (http://www.zmuc.dk/public/ phylogeny/TNT/). Instituto Superior de Entomología, Consejo Nacional de Investigaciones Científicas y Técnicas, Tucamán, Argentina.

Goris, J., Suzuki, K., De Vos, P., Nakase, T. \& Kersters, K. (1998). Evaluation of a microplate DNA-DNA hybridization method compared with the initial renaturation method. Can J Microbiol 44, 1148-1153.

Hastings, J. W. \& Nealson, K. H. (1981). The symbiotic luminous bacteria. In The Prokaryotes: a Handbook on Habitats, Isolation, and Identification of Bacteria, pp. 1332-1345. Edited by M. P. Starr, H. Stolp, H. G. Trüper, A. Balows \& H. G. Schlegel. New York: Springer-Verlag.

Haygood, M. G., Distel, D. L. \& Herring, P. J. (1992). Polymerase chain reaction and $16 \mathrm{~S}$ rRNA gene sequences from the luminous bacterial symbionts of two deep-sea anglerfishes. J Mar Biol Assoc UK 72, 149-159.

Hendrie, M. S., Hodgkiss, W. \& Shewan, J. M. (1970). The identification, taxonomy and classification of luminous bacteria. J Gen Microbiol 64, 151-169.
Klappenbach, J. A., Saxman, P. R., Cole, J. R. \& Schmidt, T. M. (2001). rrndb: the ribosomal RNA operon copy number database. Nucleic Acids Res 29, 181-184.

Lucangeli, C., Morabito, S., Caprioli, A., Achene, L., Busani, L., Mazzolioni, E., Fabris, A. \& Macri, A. (2000). Molecular fingerprinting of strains of Yersinia ruckeri serovar $\mathrm{O} 1$ and Photobacterium damsela subsp. piscicida isolated in Italy. Vet Microbiol 76, 273-281.

Mesbah, M., Premachandran, U. \& Whitman, W. B. (1989). Precise measurements of $\mathrm{G}+\mathrm{C}$ content of deoxyribonucleic acid by highperformance liquid chromatography. Int J Syst Bacteriol 39, 159-167.

Okada, K., lida, T., Kita-Tsukamoto, K. \& Honda, T. (2005). Vibrios commonly possess two chromosomes. J Bacteriol 187, 752-757.

Reichelt, J. L. \& Baumann, P. (1973). Taxonomy of the marine, luminous bacteria. Arch Mikrobiol 94, 283-330.

Swofford, D. L. (2002). PAUP*: Phylogenetic Analysis Using Parsimony ( ${ }^{\star}$ and other methods), version 4.0B10. Sunderland, MA: Sinauer Associates.

Thompson, F. L., Hoste, B., Vandemeulebroecke, K. \& Swings, J. (2001). Genomic diversity amongst Vibrio isolates from different sources determined by fluorescent amplified length polymorphism. Syst Appl Microbiol 24, 520-538.

Wheeler, W. C. (1996). Optimization alignment: the end of multiple sequence alignment in phylogenetics? Cladistics 12, 1-9.

Wheeler, W. C., Gladstein, D. \& De Laet, J. (2003). POY: phylogeny reconstruction via optimization of DNA and other data, version 3.0.11 (http://research.amnh.org/scicomp/projects/poy.php). New York: American Museum of Natural History.

Wheeler, W. C., Aagesen, L., Arango, C. P., Faivovich, J., Grant, T., D'Haese, C., Janies, D., Smith, W. L., Varón, A. \& Giribet, G. (2006). Dynamic Homology and Phylogenetic Systematics: a Unified Approach Using POY. New York: American Museum of Natural History.

Wilson, K. (1987). Preparation of genomic DNA from bacteria. In Current Protocols in Molecular Biology, pp. 2.4.1-2.4.5. Edited by F. M. Ausubel, R. Brent, R. E. Kingston, D. D. Moore, J. G. Seidman, J. A. Smith \& K. Struhl. New York: Greene Publishing \& WileyInterscience. 